\title{
Turkish Validity and Reliability of the Reproductive Coercion Scale
}

\author{
Üreme Baskısı Ölçeğinin Türkçe'ye Uyarlanması: Geçerlilik ve Güvenirlik
}

Ruşen Öztürk ${ }^{l}$ Özlem Güner ${ }^{* 2}$

\begin{abstract}
Purpose: The aim of the study was to determine the validity and reliability of the Reproductive Coercion Scale by adapting it to Turkish. Material and Methods: The present research was methodologically planned to determine the validity and reliability of the Reproductive Coercion Scale which was adapted to Turkish. The study was carried out with 150 healthy women who met the research criteria and applied to the Gynecology Polyclinic between 01 July and October 2020 in a state hospital. In the validity of the scale; Factor analysis tests (KMO, Bartlett Test, Principal Component Analysis, Varimax Rotation Method) were used to evaluate the expert opinions.In the reliability of the scale; Cronbach Alpha, pearson correlation, independent group t-test and split half values were used. Results: After ensuring the language equivalence of the Reproductive Coercion Scale, it was determined that the experts agreed on the content of the items as a result of the opinions of 10 experts $(\mathrm{p}=0.153)$ for the content validity of the five items in the scale. In the item analysis of the Reproductive Coercion Scale, the total correlation value of all items of the scale was found above 0.25 . As a result of this finding, no item was removed from the scale. The average score of the participants from the scale is $0.872 \pm 1.24$. The internal consistency reliability coefficient of the scale was found to be 0.72 and the internal consistency of the scale was found to be quite reliable. The results of the analysis of the scale's invariance against time and split half reliability also support the reliability. Conclusion: The Turkish version of the Reproductive Coercion Scale can be used validity and reliability in women.
\end{abstract}

Key words;reproductive, coercion, scale, reability, validity

ÖZET

Amaç: Çalışmanın amacı, Üreme Baskısı Ölçeği'ni (ÜBÖ) Türkçeye uyarlayarak geçerlik ve güvenirliğini belirlemektir. Gereç ve Yöntemler: Araştırma, bir devlet hastanesinde 01 Temmuz-Ekim 2020 tarihleri arasında Kadın Hastalıkları Polikliniğine başvuran, araştırma kriterlerine uyan 150 sağlıklı kadın ile metodolojik olarak gerçekleştirilmiştir. Ölçeğin geçerliliğinde; uzman görüşlerinin değerlendirilmesi Kendall $\mathrm{W}$ testi ve yapı geçerliliğinin değerlendirilmesinde faktör analizi testleri (KMO, Bartlett Testi, Temel Bileşenler Analizi, Varimax Döndürme Yöntemi) uygulanmıştır. Ölçeğin güvenirliğinde; Cronbach Alpha, pearson korelasyon, bağımsız grup t-testi ve iki yarı (Split half) değerleri kullanılmıştır. Bulgular: Üreme Baskısı Ölçeği'nin dil eşdeğerliliği sağlandıktan sonra, ölçekteki beş maddenin kapsam geçerliliği için 10 uzmanın görüşü alınmıştır ( $\mathrm{p}=0.153$ ). Üreme Baskısı Ölçeği'nin madde analizinde ölçeğin tüm maddelerinin toplam korelasyon değeri 0.25 'in üzerinde bulunmuştur. Bu bulgu sonucunda ölçekten madde çıkarılmamıştır. Katılımcıların ölçekten aldıkları puan ortalamaları $0.872 \pm 1.24$ 'tür. Ölçeğin iç tutarlılık güvenirlik katsayısı 0.72 olarak saptanmış ve ölçeğin iç tutarlılığının güvenilir olduğu belirlenmiştir. Ölçeğin zamana karşı değişmezlik ve iki yarı güvenirliğine yönelik analiz sonuçları da güvenirliği desteklemektedir. Sonuç: Üreme Baskısı Ölçeği'nin Türkçe versiyonu kadınlarda geçerli ve güvenilir olarak kullanılabilir.

Anahtar kelimeler: üreme, baskı, ölçek, güvenirlik, geçerlilik

Received / Geliş tarihi: 15.10.2020, Accepted / Kabul tarihi: 16.12.2020

${ }^{1}$ Ege Üniversitesi Hemşirelik Fakültesi, Hemşirelik Bölümü, Kadın Sağlığı ve Hastalıkları Hemşireliği Anabilim Dalı, Bornova/ İzmir TÜRKIYE.

${ }^{2}$ Sinop Üniversitesi Sağlık Bilimleri Fakültesi, Ebelik Bölümü, Sinop TÜRKIYE.

*Address for Correspondence / Yazışma Adresi: Özlem GÜNER, Sinop Üniversitesi Sağlık Bilimleri Fakültesi, Ebelik Bölümü, Sinop TÜRKIYE.

E-mail: ozcerezciozlem@gmail.com

Öztürk R, Güner Ö. Üreme Baskısı Ölçeğinin Türkçe'ye Uyarlanması: Geçerlilik ve Güvenirlik. TJFMPC, 2021;15(1): 100-109.

DOI: $10.21763 / \mathrm{tjfmpc} .810973$ 


\section{GíRiş}

Dünyadaki tüm gebeliklerin yüzde kırkını istenmeyen gebelikler oluşturmaktadır. ${ }^{1}$ İstenmeyen gebeliğin başlica önemli belirleyicisi, tutarlı ve doğru gebelik önleyici kullanım eksikliğidir. Dünya çapında, üreme çağındaki kadınların \%26'sı yani 222 milyon kadın, gebeliği önlemek veya geciktirmek istese de herhangi bir modern yöntem kullanmamaktadır., ${ }^{2,3}$ Ülkemizin en önemli kadın sağlığı araştırması olan ve her beş yılda bir yapılan Türkiye Nüfus Sağlığı Araştırması (TNSA) verilerine göre; 1993 yılında ülke genelinde isteyerek düşük yapma hızı \%23 düzeyinde iken, 2018 y1lında \%14'e düşmüştür. $^{4} \quad$ TNSA $2018 \quad$ verileri göstermektedir ki her ne kadar isteyerek düşük yapma düzeyi önceki yıllara göre azalmış olsa da, hizmet açı̆̆ı devam etmektedir. Dolayısıyla ülkemizde istenmeyen gebeliklerin belli yaş grubu ve bölgelerde artış göstermesi de bu konunun önemini göstermektedir., ${ }^{4,5}$

Her ne kadar hizmet erişimi ve politikalarda olan eksiklikler istenmeyen gebelik nedenleri olsa da, kadınların bu konuda özgürce karar vermelerini genelde ülke yaklaşımı özelde ise eşinin ona yaklaşımı etkilemektedir. Kadınlar üzerindeki kontrol, partner şiddetinin ve üreme baskısının merkezinde yer almaktadır; her iki eylemi yaşayan kadınların doğum kontrolü ve aile planlaması hakkında karar verme özerkliğine sahip olma olasılıklarının daha düşük olduğu görülmektedir. ${ }^{6} \mathrm{Bu}$ özerklik üzerinde etkili olan, kadınların doğum kontrolü kullanma ve kullanmama isteklerine müdahale eden davranışlar ile bağımsız ve kendi gücüne dayanarak karar vermelerinin engellenmesi “üreme baskı"sını oluşturmaktır.,

Üreme otonomisi, üreme baskısından farklı olarak kadının üreme sağlığına yönelik daha özgür karar verme ile güçlendirilmelerini içeren daha geniş bir çerçeve sunmaktadır. Bununla birlikte, aslında birbiriyle de yakın ilişkili kavramlar olduğu görülmektedir. ${ }^{9}$ Kadının üreme sağlığı ile ilgili özerk karar vermesini engelleyen davranışları kapsayan üreme baskısı ile üreme otonomisinin yakından ilişkili bir fenomen olduğuna yönelik kanıtlar artmaktadır. ${ }^{6,9,10}$

Üreme baskısı, eş ya da partner üzerinde üreme kontrolü ve gücünü korumak için kullandığ1 çeşitli taktikler ve davranışları içeren, eşe yönelik istismarın farklı bir türü olarak bildirilmektedir. ${ }^{11}$ Fiziksel ve cinsel şiddet varlığında, üreme baskının iki kat daha arttı̆̆1 görülmektedir. $^{12}$ Bununla birlikte herhangi bir fiziksel şiddetin olmaması durumunda da üreme baskısı şiddet içermeyen güç, kontrol ve kadın üzerinde hakimiyet şeklinde uygulanabilmektedir. ${ }^{9}$

Üreme kararı alma sürecine ek olarak, üreme baskısı; eşin gebe kalması için açık bir baskıyı ya da gebeliğini devam ettirmeye ya da sona erdirmeye zorlama, ayrıca doğum kontrolünün fiili manipülasyonunu içerebilen davranışlar olarak ortaya çıkabilmektedir. ${ }^{9}$ Son kanıtlar, bu ilişkilerin üreme kontrolüyle, yani erkek partnerlerin bir kadının üreme seçimlerini kontrol etme girişimleriyle birlikte ortaya çıktığını göstermektedir. Şiddete uğrayan kadınlar, kondom kullanımını istemeye bağlı korku duyulabilmektedirler. $\mathrm{Bu}$ doğrultuda da kontraseptif kullanımı ve aile planlaması ile ilgili sınırlı karar verme yetkisi ile karşı karşıya kalmaktadır. Kadınların üreme sağlığ1 üzerindeki kontrol eksikliği, istismara uğramış kadınların istenmeyen gebelik riskinin altında yatan kritik bir neden olarak tanınmaktadır. ${ }^{10}$ Eşin şiddetinin istenmeyen gebelikle ilişkisi, aşırı gebelik baskısı ve doğum kontrolüne doğrudan yapılan müdahaleleri içermektedir. Grace ve Anderson'un (2018) çalışmasında erkeklerin, sözel talepleri ile kadın partnerlerinin gebe kalması için tehdit ve fiziksel şiddeti kullandıkları bildirilmiştir.. Üreme kontrolü, bir kadının doğum kontrol haplarının tuvalete atılmasın1, kondomların kasıtlı olarak çıkarılmasını ve kontraseptif halkaların ya da yamaların çıkarılmasını da içerecek şekilde doğum kontrol sabotaj1- kullanmamasını sağlayan doğrudan eylemler biçiminde de olabilir. ${ }^{9}$ Batı Pensilvanya'daki 24 aile planlaması kliniğinde yapılan bir başka çalışma, son üç aydaki örneklemdeki kadınların \%5'inin "üreme baskısını" deneyimlediğini ortaya koymuștur. ${ }^{3}$ Clark ve arkadaşlarının (2010) klinik tabanlı çalışmasında, kadın doğum ve jinekoloji kliniklerinde rutin bakım alan kadınların \%16'sinın "üreme baskisı deneyimini yaşamışken, yakın zamanda yapılan bir araştırmada, yaklaşık 6000 üniversite öğrencisinin \%8'inin, klinik ortam dişında "üreme baskısını" yaşadıkları belirlenmiştir. ${ }^{13}$ Üreme baskısına yönelik sınırlı veriler, ilişkide var olan güvensizlik, doğurganlık etrafındaki erkeksi cinsiyet ideolojilerinin varlığı ve cinsel mülkiyetin sürekliliğinin üreme baskısında etkili rol oynayabileceğini belirtmektedir. ${ }^{11}$

Sonuç olarak, üreme baskısının, ilişkide var olan istismar ile örtüştüğü ayrıca, olumsuz cinsel ve üreme sağlığ 1 sonuçlarına yol açtığ 
görülmektedir. ${ }^{14}$ Üreme baskısının istenmeyen gebelikler ve kontraseptif kullanımı üzerindeki etkisine yönelik kanıtlar giderek artarken, Dünya Sağlık Örgütü'nün (WHO) üreme baskısını, özellikle aile planlaması kliniklerinde çalışan sağlık personeli tarafından değerlendirilip, dikkate alınması gereken toplumsal cinsiyete dayalı şiddetin kilit bir yönü olarak tanımladığı görülmektedir. ${ }^{15,16} \quad$ Ülkemizde üreme otonomisi ve baskısına yönelik yapılmış çalışmalar bulunmamaktadır. Ancak erkek egemen toplumsal yapı ile şiddet oranları düşünüldüğünde bu kavramların ülkemizde aile planlamasının karşılanmayan gereksinimin anlaşılmasında ve şiddetin başka bir yüzünün değerlendirilmesinde çok önemli olduğu düşünülmektedir. $\mathrm{Bu}$ doğrultuda, çalışma üreme baskına yönelik ölçeğin geçerlilik ve güvenirlik yapılarak toplumsal bazda etkisini değerlendirmeye yönelik envanter sağlamak amacıyla planlanmıştır.

\section{GEREÇ ve YÖNTEM}

Araştırmanın Tipi: Araştırma "Üreme Baskısı" ölçeğinin Türkçe formunun geçerlilik ve güvenilirliğinin yapılması için metodolojik olarak planlanmıştır. Araştırma, Karadeniz Bölgesi'ndeki bir yerleşim yerinde devlet hastanesinde Kadın Hastalıkları Polikliniğine 01 Temmuz-Ekim 2020 tarihleri arasında başvuran araştırma kriterlerine uyan 150 sağlıklı kadın ile gerçekleştirilmiştir.

Araştırmanın Örneklemi: Geçerlik ve güvenirlik çalışmalarının örneklemi belirlenirken ölçeğin madde sayısının beş ile yirmi katı civarında olması bildirilmektedir ${ }^{17}$. $\mathrm{Bu}$ bilgi 1şığında; beş maddelik ölçeğimizin örnekleminde çalışma kriterlerimize uyan 150 kadın çalışmaya dahil edilmiştir. Araştırma kapsamınahastanenin kadın hastalıkları polikliniğine başvuran, 18-49 yaş aralığındaki, okuma yazma bilen, anket sorularını cevaplamaya engel oluşturan mental sağlıkla ilgili tanı almamış, evli ya da bekar olup partneri olan ve araştırmaya katılmaya gönüllü olan kadınlar alınmıştır.

Veri Toplama Araçları: Katılımcılara iki bölümden oluşan anket uygulanmıştır. Anket formunun birinci bölümünde, bireylerin tanıtıcı özelliklerini içeren "Bireysel Tanılama Formu", ikinci bölümünde "Üreme Baskıs1 Ölçeği” yer almaktadır. Araştırma verileri araştırmacı tarafından bire-bir görüşme yöntemi kullanılarak toplanmıştır.
Birey Tanılama Formu: Form, kadınların demografik özellikleri ile aile özelliklerini içeren toplam 18 sorudan oluşmaktadır. Demografik özelliklerle ilgili olarak bireylerin yaşı, eğitim durumu, medeni durumu, mesleği, yaşadığı yer, obstetrik öyküsü ve korunma yöntemleri gibisorular yer almaktadır.

Üreme Baskısı Ölçeği: Araştırma ve klinik uygulamalarda kullanılmak üzere psikometrik özelliklerinin tanımlanması ve iyileştirilmesi amacıyla McCauley ve arkadaşları tarafindan (2017) Üreme Baskısı Ölçeği (ÜBO) geliştirilmiştir. 16-29 yaş arası 4,674 genç kadın ile yapılan çalışmada, üreme baskısının; gebeliği teşvik etmek için gebelik baskısı ve prezervatiflerin bilinçli manipülasyonunu içerdiğini göstermiştir. Ölçek uzun formu 9 maddeden oluşmakta ancak klinisyenlerin kullanım kolaylığını artırmak amacıyla 5 maddelik kısa formu Mc Cauley tarafindan oluşturulmuştur. Her madde eş ya da partnerin son üç aylık döneme ilişkin üreme baskısını belirleyen ölçek, gebelik baskısı ve kondom maniplasyonu alt boyutlarını içermektedir. Ölçekte evet/hayır (1/0) olmak üzere ikili likert şeklinde cevaplanmakta ve puanlamaktadır. ${ }^{18}$

\section{Üreme Baskısı Ölçeği’nin Dil Geçerliliği}

İngilizce dilinde olan ölçek (Reproductive Coercion Scale) Türk toplumuna uygulanabilmesi için her iki dili iyi bilen 10 akademisyen tarafından İngilizceden Türkçeye çevrilmiştir. Yapılan çeviriler kombine edilerek "Üreme Baskısı Ölçeğì"nin Türkçe formu oluşturulmuştur. İlk çevirilerdeki yanlış anlamalar veya net olmayan ifadeler, geri çeviride ortaya çıkarılmıştır. Önyargıyı önlemek için, geri çevirmenler tercihen anketin ölçtüğü düşünülen kavramların farkında olmaması gerektiği için, ölçeğin İngilizce versiyonunu daha önce görmemiş bir? dil bilimci tarafından Türkçeden İngilizceye geri çevirisi yapılarak, ölçeğin asıl sahibi tarafından farklılıklar değerlendirilmiştir. Ölçeğin Türkçe versiyonunun son hali oluşturularak dil geçerliliği sağlanmıştır. ${ }^{19,20}$

\section{Kapsam Geçerliliği Analizi}

Ölçeğin Türk dili açısından anlaşılırlığının ve kapsamının incelenmesi amacıyla uzmanlık alanları; Kadın Hastalıkları ve Doğum, Psikiyatri ve Halk Sağlığ 1 Hemşireliği Uzmanı olan 12 öğretim üyesi tarafından ölçek değerlendirilmiştir. Uzmanların ölçekteki her bir maddenin ölçüm değerinin uygunluğunu 4 puan üzerinden değerlendirmeleri istenmiştir. Uzmanların görüşlerinde istatistiksel açıdan 
anlamlı fark olmadiğ 1 bulunmuştur (Kendall's $\mathrm{W}=0.133 ; \mathrm{p}=0.153$ ).

\section{Pilot Çalışma}

Sinop Devlet Hastanesinde Kadın Hastalıkları polikliniğine başvuran 20 kadına, ölçek maddeleri uygulanarak dil ve içerik açısından anlaşılırlığ $\quad$ ve uygulanabilirliği değerlendirilmiştir. Ölçeğin maddelerine ilişkin, katılımcılar tarafından ölçeğin anlaşılabilirliğinin yeterli düzeyde olduğu belirtilmiştir. Ön uygulamadan elde edilen veriler, araştırma sonuçlarına dahil edilmemiştir. $^{21}$

\section{Verilerin Değerlendirilmesi}

Araştırma verilerinde, SPSS 21.00 programı kullanılmıştır. Araştırmaya katılan kadınların demografik özelliklerini tanımlamak için yüzdelik ve ortalama testleri; gruplara göre karşılaştırmalar içim iki ortalama arasındaki farkın önemlilik testi (t-testi), ANOVA kullanılmıştır. Ölçeğin geçerliliğinde; uzman görüşlerinin değerlendirmesi Kendall W testi ve yapı geçerliliğinin değerlendirilmesinde faktör analizi testleri (KMO, Bartlett Testi, Temel Bileşenler Analizi, Varimax Döndürme
Yöntemi) uygulanmıştır. Ölçeğin güvenirliğinde; Cronbach Alpha, pearson korelasyon, bağımsız grup t-testi ve iki yarı (Split half) değerleri kullanılmıştır.

\section{Araştırmanın Etik Yönü}

Araştırmada kullanılacak ölçeğin geçerlilik ve güvenirlik çalışmasının yapılabilmesi için elektronik posta yolu ile Dr. Mc Cauley'den izin alınmıştır. Araştırmanın yürütülebilmesi için Sinop Üniversitesi Bilimsel Etik kurulundan ve çalışmanın yapılması planlanan kurumdan yazılı izin alınmıştır (Tarihi: 23.06.2020 Karar Sayısı:2020/71). Araştırma kapsamına alınacak olan bireylerle görüşülerek, araştırmanın amacı, araştırmada sağlanacak yararlılıklar hakkında bilgilendirilmiş ve sözel onamları alınmıştır.

\section{BULGULAR}

Katılımcıların yaş ortalaması $27.95 \pm 4.43$ ve \% 96.7'si evlidir. Katılımcıların ölçekten aldıkları puan ortalamaları $0.872+1.24(0-5)$ 'dir. Katılımciların sosyo-demografik bulguları ile ÜBÖ puan ortalamaları karşılaştırılması Tablo 1 'de açıklanmıştır.

\begin{tabular}{|c|c|c|c|c|}
\hline Özellikler & $\mathbf{n}$ & $\%$ & Mean+sd & Test değeri \\
\hline \multicolumn{5}{|l|}{ Eğitim durumu } \\
\hline İlkokul & 19 & 12.7 & $0.77 \pm 1.62$ & $\mathrm{~F}=2.377$ \\
\hline Ortaöğretim & 24 & 16 & $0.41 \pm 0.88$ & $\mathrm{P}=0.072$ \\
\hline Lise & 45 & 30 & $1.22 \pm 1.44$ & \\
\hline Üniversite & 62 & 41.3 & $0.82 \pm 1.03$ & \\
\hline \multicolumn{5}{|l|}{ Çalışma Durumu } \\
\hline Evet & 92 & 61.3 & $0.90 \pm 1.30$ & $\mathrm{~T}=0.368$ \\
\hline Hayır & 58 & 33.3 & $0.82 \pm 1.16$ & $\mathrm{P}=0.714$ \\
\hline \multicolumn{5}{|l|}{ Gelir durumu } \\
\hline Kötü & 42 & 28 & $0.68 \pm 0.98$ & $\mathrm{~F}=0.669$ \\
\hline Orta & 91 & 60.7 & $0.93 \pm 1.34$ & $\mathrm{P}=0.514$ \\
\hline \multirow[t]{2}{*}{ İyi } & 17 & 11.3 & $1.00 \pm 1.27$ & \\
\hline & Mean+Sd & Min-Max & $\begin{array}{l}\text { Korelasyon } \\
\text { katsayısı (r) }\end{array}$ & $\begin{array}{l}\text { Korelasyon } \\
\text { Önem Düzeyi(p) }\end{array}$ \\
\hline Evlilik yılı & $5.50+4.07$ & $0-17$ & -0.075 & 0.369 \\
\hline Gebelik Sayısı & $1.68+1.13$ & $0-5$ & -0.056 & 0.502 \\
\hline Doğum Sayısı & $1.08+0.97$ & $0-5$ & -0.047 & 0.570 \\
\hline İsteyerek Düşük Sayısı & $0.16+0.75$ & $0-6$ & 0.377 & 0.000 \\
\hline
\end{tabular}




\section{Yapı-Kavram Geçerliği}

Ölçeğin yapı geçerliği açıklayıcı faktör analizi yöntemi ile değerlendirilmiştir. Kaiser-MeyerOlkin (KMO) testi örneklem büyüklügünün yeterliliğini değerlendirmede kullanılmıştır. ${ }^{10}$ Araştırmada KMO değeri olarak hesaplanan örneklem yeterliliği 0.775 ve Bartletts Test of Sphericity $\left(\mathrm{X}^{2}=188.272 \quad \mathrm{p}<0.00\right) \quad$ örneklem sinama büyüklüğü analizi değerinin faktör analizi için oldukça yeterli olduğu saptanmıştır. Öncelikle açıklayıcı faktör analizi olarak temel bileşenler analizi yöntemi ile boyut indirgeme uygulanmıştır. Envantere uygulanan temel bileşenler analizinde öz değeri biri aşan bir faktör olduğu saptanmıştır (Şekil 1).

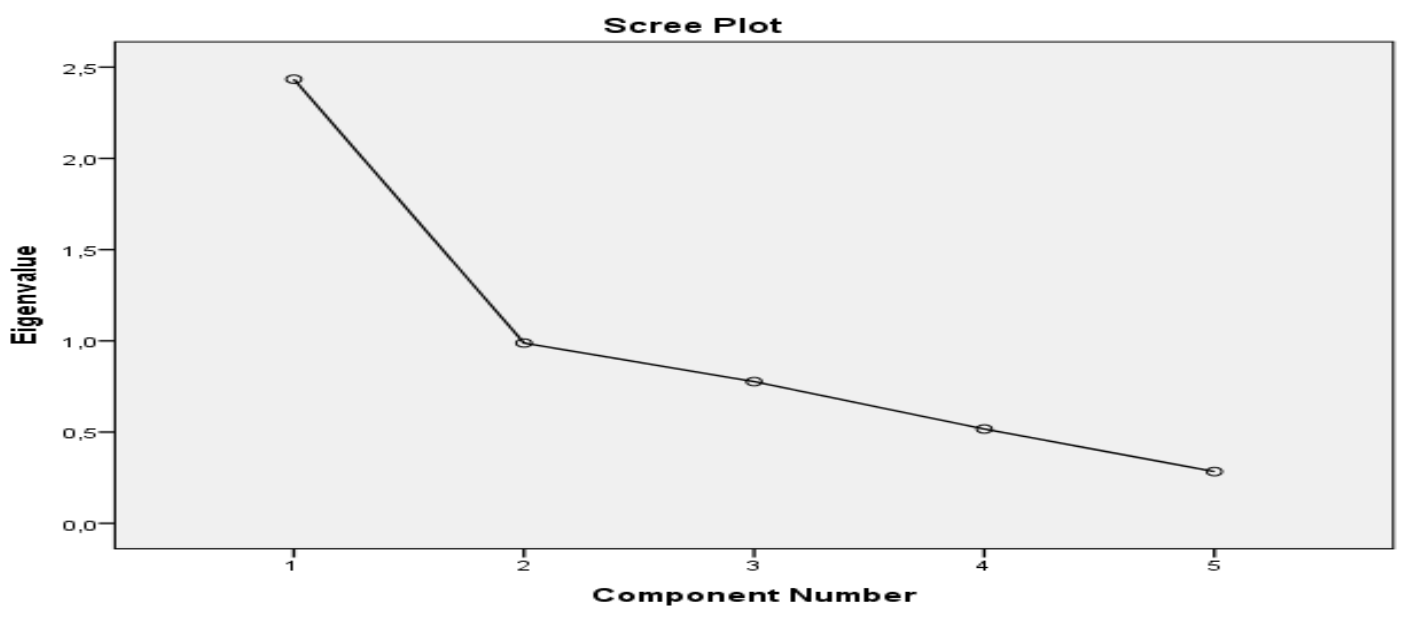

Şekil 1. Üreme Baskısı Ölçeğinin Özdeğer Eğim Grafiği (Eigenvalue of 2.43)

Varimax döndürme sonrasında ortaya çıkan tek faktörlü yap1 varyansın \%48.684'ünü açıklamaktadır. Aynı zamanda Üreme Baskısı Ölçeğinin faktör yükleri değerlendirilmiştir. Faktör yüklerinin değerlendirilmesinde 0.71 ve üzerinin kusursuz, 0.63 'ün çok iyi, $0.55^{\prime}$ 'in iyi, $0.45^{\prime}$ 'in güzel ya da kabul edilebilir ve 0.32 'nin zayıf olduğu belirtilmiștir. ${ }^{22}$ ÜBÖ’nün faktör yükleri. 54 ile. 83 arasındadır. Bulgular Tablo 2'de verilmiştir.

\section{Üreme Baskısı Ölçeği'nin İç Tutarlılık Güvenirlik Katsayısı}

Üreme Baskısı Ölçeği’nin iç tutarlılığı için yapılan analizde Cronbach alfa güvenirlik katsayısı 0.724 olarak belirlenmiştir. $\mathrm{Bu}$ değerle ölçeğin iç tutarlılığının oldukça güvenilir olduğu saptanmıştır. Araştırmaya katılanların ölçek maddelerine verdikleri yaklaşım ortalamalarının eşit olup olmadığını test etmek için Hotelling T2 testi uygulanmıştır. Yapılan analiz sonucunda yanıt ortalamalarının farklı olduğu (Hotelling $\mathrm{T}^{2}=$ 71.288, $\mathrm{p}=0.000)$, bireylerin maddeleri cevaplamakta farklı yaklaşım gösterdikleri görülmektedir.

\section{Madde - Toplam Puan Analizi}

Madde analizi sonucunda; madde-toplam korelasyonu analizinde 0.25 'in altında madde olmaması nedeniyle ölçekten madde çıkarılmamıştır (Tablo 2).

\begin{tabular}{llll|}
\hline \multicolumn{2}{l}{ Tablo 2. ÜBÖ'nün Açıklayıcı Faktör Analizi ve Madde-Toplam Puan Korelasyonları (n=150) } \\
\hline Maddeler & Faktör yükü & $\begin{array}{l}\text { Madde- toplam } \\
\text { korelasyonları }\end{array}$ & $\begin{array}{l}\text { Madde silindiğinde } \\
\text { Cronbach Alfa }\end{array}$ \\
\hline 1. Madde & 0.831 & 0.490 & 0.711 \\
\hline 2. Madde & 0.783 & 0.497 & 0.731 \\
\hline 3. Madde & 0.694 & 0.621 & 0.622 \\
\hline 4. Madde & 0.597 & 0.682 & 0.583 \\
\hline 5. Madde & 0.541 & 0.559 & 0.685 \\
\hline Özdeğer & 2.43 & & \\
\hline Açlklanan Varyans & 48.684 & & \\
\hline
\end{tabular}




\section{Yarı Test Güvenirlik Analizi}

Üreme Baskısı Ölçeği’nin; yarı test güvenilirlik sonuçları Tablo 3'de görülmektedir.

\begin{tabular}{ll}
\hline \multicolumn{2}{l|}{ Tablo 3. Üreme Baskısı Ölçeği’nin Yarı-Test Güvenilirlik Analizleri } \\
\hline Guttman Split-Half & 0.76 \\
\hline Spearman-Brown & 0.77 \\
\hline 3 Maddelik Birinci Yarı Cronbach Alfa Değeri & 0.61 \\
\hline 2 Maddelik İkinci Yarı Cronbach Alfa Değeri & 0.76 \\
\hline İki Yarı Arasındaki Korelasyon & 0.66 \\
\hline
\end{tabular}

\section{Test Tekrar Test Güvenirliği}

“Üreme Baskısı Ölçeği” üç hafta arayla 42 kadına tekrar uygulanarak korelasyon katsayısı hesaplandi. Test-tekrar test güvenilirliği katılımcıların ilk ölçek değerlendirilmesinde almış oldukları ortalama ölçek puanı 8.85. $(\mathrm{ss}=1.26)$ iken, tekrar testte ise $9.04(\mathrm{ss}=1.14)$ dir. Her iki ölçüm arasında istatistiksel açıdan anlamlı fark olmadığı saptanmıştır $(\mathrm{t}=-1.536$, $\mathrm{df}=41, \mathrm{p}=0.132)$. Üreme otonomisi toplam puanlarının ve her bir maddesinin test-tekrar test için Pearson korelasyon katsayıları hesaplanmıştır. Ölçek toplam puanlarının testtekrar testte yüksek düzeyde korelasyon gösterdiği saptanmıştır $(\mathrm{r}=0.781, \mathrm{p}<0.000)$ (Tablo 4).

Tablo 4. Üreme Baskısı Ölçeği’nin test-tekrar test araçlarının karşılaştırılması ve korelasyonları $(n=42)$

\begin{tabular}{cll} 
& Birinci uygulama & İkinci uygulama \\
\hline $\mathbf{n}$ & 42 & 42 \\
$\mathbf{X}$ & 8.85 & 9.04 \\
$\mathbf{S d}$ & 1.26 & 1.14 \\
$\mathbf{t}$ & -1.536 & \\
$\mathbf{p}^{*}$ & .132 & \\
$\mathbf{r}$ & .781 & .000
\end{tabular}

\section{TARTIŞMA}

\section{Üreme Baskısı Ölçeği'nin Geçerliği}

Geçerlik, bir envanterin ölçmeyi amaçladığ niteliği, başka bir nitelikle karıștırmadan, doğru ölçebilme derecesidir. ${ }^{23}$ Çalışmamızda envanterin geçerliğini belirlemede dil geçerliği, kapsam geçerliği ve yapı geçerliği kullanılmıştır.

Ölçek uyarlama çalışmalarının ilk basamağı olarak ölçeğin, uyarlamanın yapılacağı toplumun kültürüne yönelik dil çevirisinin yapılması gerekmektedir. Kültürler arası ölçek uyarlaması yapılırken çeviri sürecinde; çevirmen seçimi, çeviri tekniği ve geri çeviri gibi konulara çok dikkat edilmesi gerektiği belirtilir. ${ }^{22}$ İngilizce dilinde olan ölçek (Reproductive Coercion Scale) Türk toplumuna uygulanabilmesi için iki dili iyi bilen 10 akademisyen tarafindan İngilizceden Türkçeye çevrilmiş ve yapılan çeviriler kombine edilerek "Üreme Baskısı Ölçeği”'nin Türkçe formu oluşturulmuştur. İlk çevirilerdeki yanlış anlamalar veya net olmayan ifadeler, geri çeviride ortaya çıkarılmıştır. Önyargıyı önlemek için, geri 
çevirmenlerin tercihen anketin ölçtüğü düşünülen kavramların farkında olmaması gerektiği için, ölçeğin orijinalini daha önce görmemiş bir dil bilimci tarafından Türkçeden İngilizceye geri çevirisi yapılarak, ölçeğin asıl sahibi tarafindan farklilıklar değerlendirilmiştir. Envanterin Türkçe versiyonunun son hali yapılandırılarak dil geçerliliği sağlanmıştır. ${ }^{19,20}$

Kapsam geçerliliğinde; görüşü alınan uzmanlar tarafından, ölçeği oluşturan maddelerin ölçüm amacına uygunluğu, her bir maddenin amaca ne derece hizmet ettiği ve ölçeğin ölçülmek istenen alanı temsil etme durumu, ayrıca alan dışındaki farklı kavramları barındirma durumu belirlenir. ${ }^{21,24,25}$ Araştırmada "Üreme Baskısı Ölçeği'nin” dil geçerliliği sağlandıktan sonra kapsam geçerliliğinin değerlendirilmesi amacıyla ölçek 12 uzmana gönderilmiştir. Uzmanların görüşleri Kendall W analizi ile değerlendirildiğinde uzmanlar arasında uyum olduğu belirlenmiştir. $\mathrm{Bu}$ analize göre ölçeğin maddelerinin ülkemiz için anlaşılır, uygulanabilir, ölçülmek istenen alanı temsil ettiği ve ölçme amacına uygun olduğu sonucuna ulaşılmıştır. Ölçeğin dil ve kapsam geçerliği ölçütü sağlanmıştır. Dil ve kapsam geçerliliği sonrasında ölçeğin hedef örneklem kriterlerine uyan küçük grupta maddeleri anlama anlamında ön uygulama yapılması önerilmektedir. ${ }^{25} \mathrm{Bu}$ bilgiye dayanarak ölçek ön uygulaması 20 kadın ile gerçekleştirilmiştir. Ön uygulama verileri çalışma kapsamına alınmamıştır.

Yap1 geçerliği, ölçeğin hangi kavram veya nitelikleri ölçtüğünün belirlenmesini incelemektedir. Açıklayıcı Faktör Analizi (AFA); yapı geçerliği için uygulanmıştır. AFA yöntemlerinden Temel Bileşenler Analizi yöntemi ile ölçeğin maddelerinin hangi başlıklar altında gruplanabileceği belirlenmiştir. Dik açılı döndürme biçimlerinden biri olan Varimax Rotasyonu birden fazla alt boyut ortaya çıarmak amaçlanıyorsa uygulanır. Bu yöntem bir faktör altında toplanabilecek değişkenlerin sayısını minimum düzeye düşürmeye çalışır ve literatürde daha çok bu yöntemin kullanıldığ1 görülmektedir. ${ }^{26} \quad$ ÜBÖ’de AFA Yöntemlerinden Temel Bileşenler Analizi Yöntemi kullanılmış ve Varimax rotasyonu uygulanmıştır. Öz değer, faktörlerin toplam varyans içinde sorumlu oldukları varyansın miktarını gösterir. Bu değer her faktör için ayrı ayrı hesaplanır ve değeri 1'den büyük olanlar dikkate alınır. ${ }^{26}$ Üreme Baskısı Ölçeği'nin tek faktörlü çözümlemesinde faktör 1 'in yani toplam ölçek öz değeri 2.43 varyans1 \%48.68'dir. FA, maddelerin birbiri ile korelasyonlarına dayanır ve ölçekteki maddelerin farklı boyutlar altında toplanıp toplanmayacağını belirlemek için kullanılır. Faktör yüklerinin değerlendirilmesinde 0.71 ve üzerinin kusursuz, 0.63 'ün çok iyi, $0.55^{\prime}$ 'in iyi, 0.45 'in güzel ya da kabul edilebilir ve 0.32 'nin zayıf olduğu belirtilmiştir. ${ }^{20,26}$ ÜBÖ'de ölçeğin yapı geçerliliğinde faktör yapısını ortaya koyabilmek için yapılan AFA sonucunda ölçek maddeleri tek faktörlü yapı altında toplanmıştır. Maddelere ait faktör yüklerinin de 0.83- 0.54 arasında değiştiği görülmektedir (Tablo 2). Madde faktör yükleri sonucunda ölçekteki her bir maddenin kavramsal yapıyla ilgili olduğu sonucuna ulaşılmıştır.

Yapılan geçerlilik analizlerinde ÜBÖ'nün orijinal ölçekteki gibi iki faktörlü yap1 göstermediği görülmüştür. ÜBÖ’nün orijinal dili İngilizcedir ve geçerlilik ve güvenilirlik çalışmaları US ‘de aile planlaması kliniğine başvuran ve sadece \%7.6'si evli kadınlara uygulanan anketler sonucunda yapılan analizlerle ortaya konmuştur. Çevirilerin ölçeğin orijinal dilindeki anlamı tam olarak karşılayamaması, ölçeğin orijinalinin toplumumuza göre demografik özellikler ve kültürel yönden farklılıkların çok olması ölçeğin farklı bir faktör yapısı göstermesine sebep olarak gösterilebilir.

\section{Üreme Baskısı Ölçeği'nin Güvenirliği}

Güvenirlik, ölçme amaçlı veri toplama araçları için vazgeçilmez olan bir özelliktir. Kavramsal ve istatiksel olarak güvenirlik, bir testteki gerçek farklılıkların, toplam farklılığa oranıdır. Bir ölçeğin güvenirlik katsayısının bulunmasında birden fazla yöntemden yararlanılabilir. ${ }^{27}$ Çalışmamızda güvenirliği belirlemede iç tutarlılık güvenirlik katsayısı, madde analizi, iki yarıya bölme güvenirlik katsayısı ve zamana karşı değişmezlik (testtekrar test), yöntemleri kullanılmıştır.

Ölçek geliştirme ve uyarlama çalışmalarında iç tutarlılık güvenirlik katsayısı en çok kullanılan yöntemlerden biridir. ${ }^{28} \mathrm{Bu}$ nedenle güvenirlik değerlendirilmesinde bu katsayının hesaplanması gerekir. İç tutarlılık güvenirlik katsayı 0 ile 1 arasında değer almaktadır. Değerlendirme ölçütüne göre; $.00<\alpha<.39$, ölçek güvenilir değildir; $.40<\alpha .<59$, ölçek düşük güveniirliktedir; . $60<\alpha<.79$, ölçek oldukça güvenilir; . $80<\alpha<1.00$ ise ölçek yüksek derecede güvenilir olarak kabul edilmektedir. ${ }^{25,29} \mathrm{Bu}$ çalışmada Üreme Baskısı Ölçeği'nin iç tutarlılık güvenirlik katsayısı 
0.72 olarak belirlenerek envanterin oldukça güvenilir olduğu belirlenmiştir. Sonuç olarak; ölçekte bulunan maddelerin birbiri ile tutarlı ve ölçülmek istenen değişkeni temsil ettiği belirlenmiştir.

Ölçeğin iç tutarlılığını değerlendirmede kullanılan bir başka yöntemde madde analizidir. Ölçek maddeleri eşit ağırlıkta ve bağımsız üniteler şeklinde ise, her madde ile toplam değerler arasındaki korelasyon katsayısının yüksek olması beklenir. Korelasyon katsayısı ne kadar yüksekse o maddenin ölçülmek istenen özellikle ilişkisi o derece yüksektir. Madde toplam puan korelasyon katsayısının ne zaman yetersiz sayılacağ1 konusunda belirli bir standart bulunmamaktadır. Ancak, korelasyonların negatif olmaması ve hatta 0.25 veya 0.30 'un üzerinde ve 0.70 'den küçük olması önerilmektedir. ${ }^{19,20}$ Ölçeğim? maddeleri, madde ve toplam puan korelasyon katsayıları yönünden değerlendirilmiştir (Tablo 2). Korelasyon güvenilirlik katsayılarının 0.49 ile 0.68 arasında olduğu saptanmıştır. Çalışmamızda, madde analizi sonucunda toplam korelasyonu 0.25 'nin altında olan madde olmadığından ölçekten madde çıkarılmamıştır. Kısacası, madde-toplam korelasyonlarının yeterli düzeyde olduğu bulunmuştur.

Envanterin iki yarıya bölünmesi yöntemiyle hesaplanan güvenirlik katsayısı, eşdeğer iki yarı güvenirliği olarak bilinmektedir. İki yarıya bölme yönteminde; yapılan güvenirlik ölçümlerinde ölçeğin maddeleri yansız olarak iki eşit gruba ayrılarak her gruptaki toplam puanlar, testin uygulandığı herkes için, ayrı ayrı hesaplanır. Bölünmüş test puanları arasındaki ilişki belirlemede korelasyon katsayısı kullanılmaktadır. Ölçek güvenirliğini saptamada en çok kullanılan yöntemlerden biridir. $^{30}$ Üreme Baskısı Ölçeği'nin yarı test güvenirlik analizlerinde Guttman Split-Half, Spearman-Brown katsayısı ve iki yarı arasındaki korelasyon katsayısı yüksek düzeyde saptanmıştır. Bu sonuçlar envanterin güvenilir ve kabul edilebilir iç tutarlılığa sahip olduğunu göstermektedir.

Test-tekrar test güvenirliği bir ölçme aracının kararlılığını ve aracın değişik zamanlardaki tekrarlı ölçümlerde benzer ölçüm değerlerini sağlama niteliği ile ilgilenmektedir. ${ }^{26}$ Test tekrar test güvenirliğini belirlemede kullanılan korelasyon katsayısının 0 ile 1 arasında olmasi gerekmektedir. Literatüre baktığımızda; korelasyon değeri
0.20 ve küçük olduğunda çok zayıf ilişki, 0.200.39 arasında ise zayıf ilişki, 0.40-0.59 arasında ise orta, 0.60-0.79 arasında ise yüksek, 0.80-1.0 ise çok yüksek ilişki olduğu şeklinde yorumlanır. ${ }^{28,31}$ Üreme Baskıs1 Ölçeği'nin test-tekrar test korelasyon katsayısının 0.781 olduğu belirlenmiştir. Üreme Baskısı Ölçeği'nin üç hafta arayla yapılan ölçüm puanları arasında pozitif yönde, güçlü ve istatistiksel olarak ileri düzeyde anlamlı bir ilişki olduğu belirlenmiştir $(\mathrm{p}<0.05)$. Türkçeye çevrilen Üreme Baskısı Ölçeği'nin zamana bağlı olarak değişim göstermediği ve güvenilir olduğu belirlenmiştir. Test-tekrar test korelasyon katsayısı yeterli düzeyde olsa da, iki ölçüm sonuçlarının puan ortalamalarının ve standart sapmalarının değerlendirilmesi ve her iki ölçüm sonucunun benzer olması gerekliği vurgulanmaktadır. ${ }^{32} \mathrm{Bu}$ doğrultuda test ve tekrar testten elde edilen puan ortalamaları "bağımlı gruplarda t testi" ile analiz edildiğinde, üç hafta ara ile yapılan ölçümün puan ortalamaları arasında istatistiksel olarak anlamlı fark saptanmamıştır $(\mathrm{p}>0.05) . \mathrm{Bu}$ sonuçlar Türkçe Üreme Baskısı Ölçeği'nin zaman içinde ölçeğe bağlı değişkenlik göstermeyerek sabit kaldığını belirtmektedir.

\section{SONUÇ}

Sağlayıcılar tarafından, şiddetin bir formu olan üreme baskısını da içerecek şekilde şiddet taramasının yapılması, risk altında olan kadınları tanımlamak için ilk adım olmalıdır. ${ }^{33}$ Şiddet ve üreme baskısı konusunda hemşirelerin eğitimi, genç kadınlar arasında üreme baskısı bilincini arttırmak, istismar uğrayan kadınların güvenliğini sağlamak ve istenmeyen gebelik riskini azaltmak için oldukça önemlidir. ${ }^{12}$ Hemşireler, kadınların ilişki durumlarını, şiddetin ortaya çıkışını, baskıyı ve daha güvenli ilişki konusunda müzakere etme yeteneğini değerlendirmelidirler. $\mathrm{Bu}$ görüşmeler, rutin ziyaretler sırasında kadınların güvenliği ile ilgili tartışmalar çerçevesinde düzenlenmelidir. Böylece, kadınların en uygun ve etkili doğum kontrol yöntemini seçmelerine yardımcı olunacaktır. $^{33} \mathrm{Bu}$ kısa form ölçeğin, bu amaçla, aile planlaması sağlayıcıları tarafından üreme baskısının hızlıca değerlendirilmesine olanak sağlayacağı düşünülmektedir. Ölçeğin orijinali iki alt boyut ve 5 maddeden oluşurken, Türkçe versiyonunun tek boyut ve 5 maddeli yapı ile kullanımı uygun bulunmuştur. Ölçek bu yapısıyla özgün formun güvenirliğine uygun bulunmuştur. Ölçeğin daha geniş örneklem grubu ile tekrar sinanması, genellenebilirliğini sağlayacaktır. Üreme 
baskısı ölçeğinin, kadınların üreme baskısını etkileyen faktörlerin belirlenmesinde kullanılması önerilir.

\section{KAYNAKLAR}

1. Singh S, Maddow-Zimet I. Facility-based treatment for medical complications resulting from unsafe pregnancy termination in the developing world, 2012: a review of evidence from 26 countries. BJOG An Int J Obstet Gynaecol. Ağustos 2016;123(9):1489-98.

2. Darroch JE, Singh S. Trends in contraceptive need and use in developing countries in 2003, 2008, and 2012: an analysis of national surveys. Lancet. May1s 2013;381(9879):1756-62.

3. Upadhyay UD, Dworkin SL, Weitz TA, Foster DG. Development and validation of a reproductive autonomy scale. Stud Fam Plann. 2014;45(1):19-41.

4. TNSA. Türkiye Nüfus ve Sağlık Araştırması Ankara: Hacettepe Nüfus Etütleri Enstitüsü Yayınlar1. 2018. $53 \mathrm{~s}$.

5. TNSA. Türkiye Nüfus ve Sağlık Araştırması Ankara: Hacettepe Nüfus Etütleri Enstitüsü Yayınlar1. 2013. 75-95s.

6. Chamberlain L, Levenson R, Lee $\mathrm{NC}$, Langhorne A, Kelley M, Miller E, vd. Addressing Intimate Partner Violence, Reproductive and Sexual Coercion: A Guide for Obstetric, Gynecologic and Reproductive Health Care Settings. https://www.futureswithoutviolence.org/userfil es/file/HealthCare/reproguidelines low res_FI NAL.pdf Erişim Tarihi: 17.09.2020,2012

7. Fay K, Yee L. Reproductive Coercion and Women's Health. J Midwifery Womens Health. 01 Eylül 2018;63(5):518-25.

8. Brandi K, Woodhams E, White KO, Mehta PK. An exploration of perceived contraceptive coercion at the time of abortion. Contraception. 01 Nisan 2018;97(4):329-34.

9. Grace KT, Anderson JC. Reproductive Coercion: A Systematic Review. C. 19, Trauma, Violence, and Abuse. SAGE Publications Ltd; 2018. s. 371-90.

10. Kirk J, Marc L, Miller. Reliability and Validity in Qualitative Research. London: A Sage University Paper; 2014. 324-336 s.

11. Thaller J, Messing JT. Reproductive Coercion by an Intimate Partner: Occurrence, Associations, and Interference with Sexual Health Decision Making. Heal Soc Work. 24 Şubat 2014;41(1):e11-9.

12. Miller E, Decker MR, McCauley HL, Tancredi DJ, Levenson RR, Waldman J, vd. Pregnancy coercion, intimate partner violence and unintended pregnancy. Contraception. Nisan 2010;81(4):316-22.
13. Clark J, Edward Haskins, Haskins C. Reproductive systems in the myxomycetes: a review. Mycosphere. 2010;1(4):337-53.

14. Hill AL, Jones KA, McCauley HL, Tancredi DJ, Silverman JG, Miller E. Reproductive Coercion and Relationship Abuse Among Adolescents and Young Women Seeking Care at School Health Centers. Obstet Gynecol. 01 Ağustos 2019;134(2):351-9.

15. Silverman JG, Boyce SC, Dehingia N, Rao N, Chandurkar D, Nanda P, vd. Reproductive coercion in Uttar Pradesh, India: Prevalence and associations with partner violence and reproductive health. SSM - Popul Heal. 01 Aralık 2019;9:100484.

16. WHO. WHO | Strengthening health systems to respond to women subjected to intimate partner violence or sexual violence: [Internet]. WHO. World Health Organization; 2017 [kaynak 18 Eylül 2020]. Available at: http://www.who.int/reproductivehealth/publica tions/violence/vaw-health-systems-manual/en/ 17. Büyüköztürk S. Manual of data analysis for social sciences. Ankara: Pegem Academy;2011. 174-180 s.

18. McCauley HL, Silverman JG, Jones KA, Tancredi DJ, Decker MR, McCormick MC, vd. Psychometric properties and refinement of the Reproductive Coercion Scale. Contraception. 01 Mart 2017;95(3):292-8.

19. Guillemin F, Bombardier C, Beaton D. Cross-cultural adaptation of health-related quality of life measures: Literature review and proposed guidelines. $\mathrm{J}$ Clin Epidemiol. 1993;46(12):1417-32.

20. Tsang S, Royse CF, Terkawi AS. Guidelines for developing, translating, and validating a questionnaire in perioperative and pain medicine. C. 11, Saudi Journal of Anaesthesia. Medknow Publications; 2017. 80-9 s.

21. Tavşancil E. Measurement of attitudes and data analysis with SPSS.5. Bask1. Ankara: Nobel Yayıncılık; 2014. 244-249 s.

22. Çapık C, Gözüm S, Aksayan S. Kültürlerarası Ölçek Uyarlama Aşamaları, Dil ve Kültür Uyarlaması: Güncellenmiş Rehberama Aşamaları, Dil ve Kültür Uyarlamas1: Güncellenmiş Rehber Intercultural Scale Adaptation Stages, Language and Culture Adaptation: Updated Guideline. Florence Nightingale J Nurs. 2018;26(3):199-210.

23. Ercan İ, Kan İ. Ölçeklerde Güvenirlik ve Geçerlik. Uludağ Üniversitesi Tıp Fakültesi Dergisi 2004;30 (3)211-16.

24. Sümbüloğlu V, Sümbüloğlu K. Sağlık bilimlerinde araştırma yöntemleri. Ankara: Hatipoğlu Yayınları; 2000. 178-180 s. 
25. Aksayan S, Gözüm S. Kültürlerarası ölçek uyarlaması için rehber I: Ölçek uyarlama aşamaları ve dil uyarlaması. Hemşirelik Araştırma Derg. 2002;4(1):9-14.

26. Şencan H. Reliability and validity in social and behavioural measurements. Ankara, Turkey: Seçkin; 2005. 255-274 s.

27. Alpay R. Uygulamalı çok değişkenli istatistiksel yöntemlere giriş.Detay yayıncılık. 2003. 375-393 s.

28. Karasar N. Bilimsel Araştırma Yöntemi. Ankara: Nobel Yayınc1lı; 2008. 67-79 s.

29. Özdamar K. Statistical data analysis with packet programs (7th ed.). Eskisehir, Turkey: Kaan Bookstore; 2009. 274-275 s.
30. Timothy A, Brown. Confirmatory Factor Analysis for Applied Research . Guilford; 2015. 380-396 s.

31. Akgül A. Statistical analysis SPSS practices techniques in medical research (3rd ed.). Ankara, Turkey: EmekOfset; 2005. 384 s. 32. Çimen S, Bahar Z, Öztürk C, Bektaş M. AIDS tutum ölçeğinin geçerlik ve güvenirlik çalışması. Zo Sağlık Yüksekokulu Sağlık Eğitim Araştırma Derg. 2005;1(1):1-11.

33. Sutherland M, Fantasia HC, Fontenot HB. Reproductive Coercion and Partner Violence Among College Women. J Obstet Gynecol Neonatal Nurs. 01 Haziran 2015;44(s1):S56. 